\title{
Escafoide tripartido
}

Tripartite scaphoid

David Gonçalves Nordon ${ }^{1}$

O escafoide é um osso de apenas um centro de ossificação. Dois centros são raros; três centros, como observado neste caso, são extremamente raros e, às vezes, só são diferenciados de tumores por meio de ressonância nuclear magnética. ${ }^{1}$

Podem-se observar na radiografia anteroposterior da mão os três núcleos do escafoide (Figura 1), confirmados pelos cortes coronais da ressonância nuclear magnética, na qual se observa também a união desses núcleos por tecido cartilaginoso. Os outros ossos do carpo são normais, e o paciente apresenta uma ulna minus.

Clinicamente o paciente apresentava deformidade no dorso de sua mão, na topografia do escafoide. Optou-se por seguimento clínico e, caso haja comprometimento funcional futuro, excisão dos núcleos com cirurgia corretiva do escafoide (Matte-Russe ou Fisk-Fernandez).

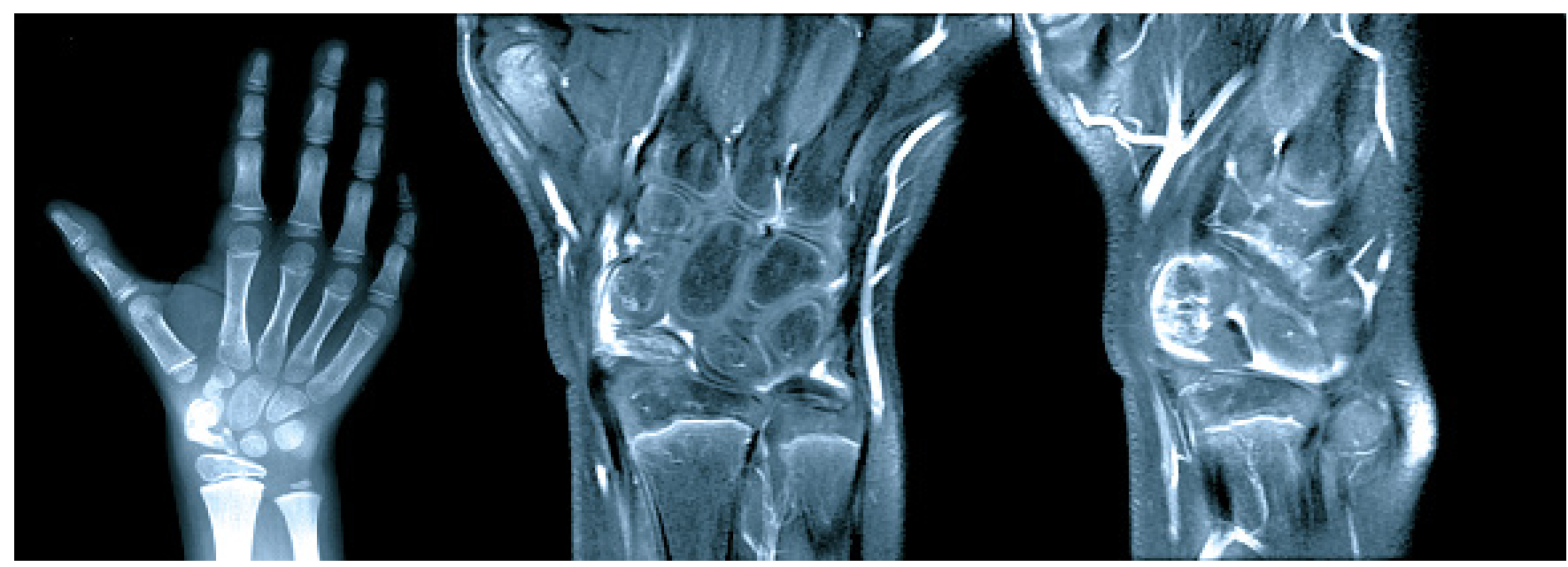

Figura 1. Observa-se uma radiografia em incidência anteroposterior, um corte coronal e um corte sagital em ponderação T2 de uma ressonância do punho e mãos, nos quais notam-se os três núcleos de ossificação do escafoide.

\section{REFERENCIAS}

1. Bucholz RW, Heckman JD, Court-Brown CM, Tornetta III P, McQueen MM, Ricci WM. Rockwood and Green's Fractures in Adults. 7th edition. Philadelphia: Lippincott Williams \& Wilkins, 2010. $2296 \mathrm{pp}$.

${ }^{1}$ Faculdade de Medicina, Hospital de Clínicas, Instituto de Ortopedia e Traumatologia, Universidade de São Paulo (USP) São Paulo (SP), Brasil.

Contato: nordondg@gmail.com

Recebido em 31/03/2016. Aceito para publicação em 04/05/2016 